J. Dairy Sci. 93:4997-4997

doi:10.3168/jds.2010-93-10-4997

(C) American Dairy Science Association ${ }^{\circledR}, 2010$.

\title{
Erratum to "Milk fatty acids in dairy cows fed whole crude linseed, extruded linseed, or linseed oil, and their relationship with methane output" (J. Dairy Sci. 92:5199-5211)
}

Y. Chilliard, C. Martin, J. Rouel, and M. Doreau

On page 5204 (left column, last line), the sign of the coefficient should be changed $[-80.1( \pm 60.9)$ should be $+80.1( \pm 60.9)]$. The corrected equation should read as follows:

$$
\begin{gathered}
\mathrm{CH}_{4} \text { output }(\mathrm{g} / \mathrm{d})=-100.8( \pm 22.0) \times \text { milk } \\
\text { trans- } 16+\text { cis-14 18:1 }(\% \text { of total FA })+6.78( \pm 1.75) \\
\times \text { milk 16:0 }(\% \text { of total FA })+13.1( \pm 3.86) \\
\times \text { forage intake }(\mathrm{kg} \text { of } \mathrm{DM} / \mathrm{d})+80.1( \pm 60.9) .
\end{gathered}
$$

The authors apologize for this error.

Chilliard, Y., C. Martin, J. Rouel, and M. Doreau. 2009. Milk fatty acids in dairy cows fed whole crude linseed, extruded linseed, or linseed oil, and their relationship with methane output. J. Dairy Sci. 92(10):5199-5211. 